\title{
Work Environment and Organizational Learning as Key Drivers of Employee Productivity: Evidence from Higher Education Sector
}

\author{
Jalal Hanaysha \\ Senior Lecturer, Faculty of Business and Management \\ DRB-HICOM University of Automotive Malaysia, 26607, Pekan, Pahang, Malaysia \\ E-mail: jalal.hanayshi@yahoo.com
}

Received: February 02, 2016 Accepted: February 27, 2016 Published: April 04, 2016

doi:10.5296/ijhrs.v6i2.9203 URL: http://dx.doi.org/10.5296/ijhrs.v6i2.9203

\begin{abstract}
Improving employee productivity is one of the main objectives for any organization. This is because high employee productivity can lead to positive organizational outcomes. This study aims to examine the effects of work environment and organizational learning on employee productivity in higher education sector. The data was collected using a survey instrument from 242 employees at public universities in northern Malaysia. The collected data was then coded and analysed using SPSS and structural equation modelling (AMOS). The findings indicated that work environment had significant positive effect on employee productivity. The findings also indicated that organizational learning had significant positive effect on employee productivity. These results provide beneficial suggestions for policy makers to formulate the relevant strategies in terms of work environment and organizational learning for the purpose of improving the productivity of employees to achieve competitive advantages and favourable organizational outcomes.
\end{abstract}

Keywords: Employee productivity, Organizational learning, Work environment 


\section{Introduction}

The concern towards improving employee productivity has been increasing in the recent years. This is because higher levels of productivity can help organizations enhance their profits and increase employees' wages, which could lead to increased organizational performance and greater economy outcomes (Greef et al., 2004). Productivity represents the power of an employee to utilize certain goods and services which can be provided at a particular state, technique, and organization to come up with something that is valuable (Lambert, 2000). According to Saari (2006), productivity is a measure of the output based on a production process per unit. In other words, employee productivity refers to the amount or quantity of output that an employee produces over a specific period of time.

Many organizations associate the productivity of their employees to skill acquisition. However, most of the issues in employee productivity come from organizational work environment. Taiwo (2010) demonstrated that work environment is one of the main factors that could affect employees' performance. The conditions of work environment where employees do their works determine the way in which such organizations prosper. Moreover, a conducive working environment reinforces employees' well-being, and this would enable them to exert high efforts in doing their tasks with higher motivation that is necessary to higher productivity levels (Akinyele, 2007). For these reasons, in order to survive and grow in a market environment that is characterized by high competition; organizations are responsible for ensuring appropriate working environment to increase employees' performance (Taiwo, 2010).

Organizational learning is another important factor that can help organizations improve employee productivity. As the human resources are considered the most valuable asset in any organization, it is very important to enrich the learning and education among employees in order to achieve the status of a learning organization that enjoys high performance. Organizational learning indicates that employees learn inside the organization. It is mainly applied to describe certain kinds of activities within an organization (Abdi \& Khodadadi, 2014). In other words, organizational learning refers to the process of creating, maintaining, and transferring the best of knowledge within the organization. The advantage of organizational learning is that it allows an organization to remain competitive despite the changing environment.

However, despite the importance of work environment and organizational learning in affecting employee productivity, empirical research on this topic is limited, particularly in service sectors. Moreover, to date, there are few empirical studies that have been conducted on employee productivity. Therefore, the purpose of this paper is to examine the effects of working environment and organizational learning on productivity in Malaysian higher education sector. The outcomes of this study would provide useful guidelines and suggestions for policy makers to deal with the issues of productivity at workplace. The next section starts by the literature review about the variables and reviewing empirical researches which examined the link between them. Followed by is the methodology used for data collection, and then, the results, discussion and conclusion are presented. 


\section{Literature Review}

\subsection{Employee Productivity}

Productivity entails achieving the highest level of performance with the lowest usage of resources. According to Adamu (1991), productivity represents the relation between the output and input. Mali (1978) described productivity as the extent to which the resources in an organization are brought together and utilized for accomplishing a set of outcomes. Taiwo (2010) indicated that the term employee productivity refers to the amount of products and services that are produced or rendered by an employee within a certain period of time (yearly, monthly, weekly, daily or per an hour). Similarly, Rollison (2008) expressed employee productivity as the amount of employee's output as a result of using certain inputs and it can be affected by different factors such as: skills, attitudes, and characteristics, including official training, qualifications, motivation, initiative, team abilities, attention to detail, judgement, multi-task abilities, communication skills, common attitudes and work philosophy.

Productivity is somewhat easy to comprehend and measure in manufacturing contexts, but as business economies have shifted from manufacturing to service context and on a knowledge-based, thus, the entire issue of evaluating productivity has not become clear (Mawson, 2002). Abdi and Khodadadi (2014) illustrated that productivity entails continually implementing actions and tasks in an appropriate and precise way. The authors added that efficiency and effectiveness are the key components of productivity. In other words, it can be evaluated through the skill in ideal exploitation of resources (human resources, equipment, and material) to make correct decisions and doing things right. One of the key strategies that organizations can use to improve productivity is the assurance of comfortable working environment and well-being of their employees (Foldspang et al., 2014). Such activities would lead positive organizational outcomes and continued success..

\subsection{Work Environment}

Literally, the term environment refers to the surroundings and anything that affects human being throughout the lifetime. In business context, a working environment refers to the environment where employees work collectively to achieve organizational objectives (Awan \& Tahir, 2015). According to Nakpodia (2011), a good working environment exists when all the essential needs and facilities that could help employees do their works are provided. Such facilities and needs include decent furniture, air conditioned offices, teaching facilities and materials, pleasant communications and network of information technology, good working atmosphere, and exposed organizational climate. From a broader perspective, work environment can be described as the location where employees perform their tasks. Similarly, Sikalieh and Mutia, (2014) referred work environment to the physical geographical location of a job and its close surroundings (generally the instruments and equipments that are vital to the performance of diverse tasks for doing the job). Vischer (2007) also expressed work environment according to the integration of psychosocial dimensions that include employer relationship, motivation and progression, career demands, and social support. 
In today's business world, the environment of a workplace is regarded as the most important factor for developing employee satisfaction as today's workplaces are different, varied, and regularly changing (Ajala, 2012). This has urged organizations to realize the significance of employee comfort at workplace and improve the functional ergonomic features in order to maintain quality personnel, increase productivity, and enhance competitive advantage. Therefore, the quality of a workplace environment has a significant influence on the level of employees' motivation and organizational performance. How well they feel involved with their organization, particularly with their close environment, affects to a large extent their levels of innovation, relationships with other employees, absenteeism, and willingness to stay in the organization (Sehgal, 2012).

The work environment as described by Opperman (2002) consists of three main sub environments: human environment, organizational environment, and technical environment. The author explained that human environment represents the peers, others with whom the workers relates, work group team, interactional issues, leadership style, and the management of an organization. The human environment is designed in a way that inspires informal communications at the work place so that the opportunities for knowledge sharing and exchange of ideas could be reinforced. On the other hand, organizational environment refers to the systems, rules, practices, values, and philosophies where the management controls over them. Finally, the technical environment includes the tools, equipment, technological infrastructure, and other technical elements.

In general, work environment plays an important role in improving organizational outcomes. Brenner (2004) demonstrated that work environment should be designed to fulfil employees' satisfaction and ensure the free flow of ideas exchange, and this leads to motivating employees towards achieving higher productivity. Thus, when work environment is appropriately designed, it would motivate the employees to increase their productivity levels. Ali, et al. (2013) found that the productivity of employees could be increased by maintaining working conditions and work environment up to certain standards. Awang and Tahir (2015) also confirmed that work environment is necessary to increase employees' productivity. They added that, factors such as supervisor support, worthy relationships with co-workers, training and development programs, attractive incentives and recognition plans, and reasonable work load are vital to create a working environment that can affect employees' productivity. Based on the above discussion, the following hypothesis is proposed:

H1: Work environment has positive effect on employee productivity.

\subsection{Organizational Learning}

Learning is a dynamic process which steadily changes from an individual learning to organizational learning. As organizations need to adapt to environmental changes, the concept of learning organization has become gradually popular (Abdi, \& Khodadadi, 2014). Therefore, learning is very important for employee's development and the organization as a whole. Organizational learning can be viewed as a set of processes that lead to management and training practices, thus, it can be used for creating a learning organization (Love et al., 2000). Vasenska (2013) suggested two important mechanisms for effective organizational 
learning and professional development. This includes providing the necessary information about teaching and learning, besides encouraging the interaction between teachers and workers. As a result, a learning organization focuses on promoting, facilitating, and rewarding a collective learning. Such learning activities would lead to competitive advantage and positive organizational outcomes.

A number of studies (Huber, 1991; Dale, 1994; Winter, 2000) proposed four dimensions of organizational learning process and this includes: knowledge acquisition, dissemination, application, and translation into organizational memory. On the other hand, Dale (1994) revealed that organizational learning can be categorized into three stages process including knowledge acquisition, dissemination, and joint application (interpretation). From the above views, it can be said that organizational learning process starts from knowledge acquisition, dissemination, to application and sharing of knowledge between organization members (AbbasKhani et al., 2013). This organizational learning process increases the performance levels among employees through more knowledge and understanding. Moreover, through nurturing staff knowledge, the level of organizational intelligence would be improved and also employees' productivity would be stimulated.

Past studies reported that organizational learning had a significant positive impact on employee productivity (Abdi \& Khodadadi, 2014; Allen et al., 2002; AbbasKhaniet al., 2013; Vasenska, 2013). Asadi et al. (2009) illustrated that in order to increase employees' productivity, it is important is to improve their professional knowledge and organizational information. As a result, physical organizational education authorities of education should put greater emphasis on learning at different levels in an organization and professionals. Furthermore, Watkins and Marsick (1992) declared that frequent learning leads to innovation and creativity which are fundamental to productivity. Argote and Miron-Spektor (2011) also supported this view indicating that employees who are usually more productive are those who have specialized experiences. Based on the discussion presented above, the following hypothesis is proposed:

$\mathrm{H} 2$ : Organizational learning has positive effect on employee productivity.

\section{Methodology}

The study follows the quantitative research approach for data collection. Specifically, a survey questionnaire was designed to examine the impact of workplace environment and organizational learning on employee productivity. The population of this study is comprised of public universities' employees in northern Malaysia. Therefore, to fulfil the objectives of this study, the designed questionnaire is distributed on the respondents using an online survey during different times of the day. The reason for using online survey is to ensure that the employees can answer the questionnaires in their convenient times. According to Yoldas (2012), survey method is more rigid than interviews and is usually utilized to gather information from a large number of populations. In general, this study distributed 870 questionnaires to the targeted respondents (academicians and administrative staff) and only 242 were willing to participate in the survey. 
The instrument developed for this study consisted of three sections. Section A included a set of questions about the demographic characteristics of participants such as gender, age, educational qualifications, and length of work experience. Section B included the questions to measure work environment and employee productivity. The scale of work environment was adapted from the study of McGuire and McLaren (2009), because the items were reported at an acceptable reliability with a Cronbach's alpha value of more than 0.70 . To measure employee productivity, a five items scale was adapted from Chen and Tjosvold (2008); Lee and Brand (2010). Finally, section C included seven questions to measure organizational learning. The measurement scale was taken from Joo and Park (2010). All the items were measured on a five-point Likert scale ranging from 1 "strongly disagree" to 5 "strongly agree". The collected data was then analysed using SPSS 19 and structural equation modelling through AMOS 18. In the following section, the analysis of results is presented.

\section{Analysis of Results}

The demographic profile as illustrated in Table 1 reveals that $65(26.9 \%)$ of the respondents are male, while $177(73.1 \%)$ are female. Most of the respondents $(50 \%)$ belong to the age group of 26 to 35 years old, followed by 98 (40.5\%) in the age category of 36 to 45 years. Those whose ages ranged from 18 to 25 years accounted for $2.9 \%$ of total response, and only $16(6.6 \%)$ were 46 years and above. On educational profile, $36(14.9 \%)$ of the respondents acquire diploma degree, $79(32.6 \%)$ had undergraduate qualification, $125(51.7 \%)$ had postgraduate degree, and only $2(0.8 \%)$ had other professional certificates. The majority of respondents $(69 \%)$ had more than 5 years of work experience at their current institutions.

Table 1. Respondents' Profile

\begin{tabular}{llcc}
\hline & Category & Frequency & Percent \\
\hline Gender & Male & 65 & 26.9 \\
& Female & 177 & 73.1 \\
\hline Age & $18-25$ years & 7 & 2.9 \\
& $26-35$ years & 121 & 50 \\
& $36-45$ years & 98 & 40.5 \\
& 46 years and above & 16 & 6.6 \\
\hline Qualification & Diploma & 36 & 14.9 \\
& Undergraduate & 79 & 32.6 \\
& Master & 74 & 30.6 \\
& Doctorate & 51 & 21.1 \\
& Others & 2 & 0.8 \\
\hline Work Experience & Less than 1 year & 12 & 5 \\
& 1 vear - 2 vears & 23 & 9.5 \\
& Between 2 years and 5 years & 40 & 16.5 \\
& More than 5 years & 167 & 69 \\
\hline
\end{tabular}

To examine the reliability of constructs, the Cronbach's alpha was used. The results indicated that the Cronbach's alpha values of all constructs were satisfactory ranging from 0.75 to 88 . Specifically, work environment is reported at a Cronbach's alpha value of 0.83 . 


\section{Macrothink}

International Journal of Human Resource Studies

ISSN 2162-3058 2016, Vol. 6, No. 2

Organizational learning also achieved a Cronbach's alpha value of 0.88 . Finally, employee productivity is reported at an acceptable reliability with a Cronbach's alpha value of 0.75 . Based on these findings, it can be said that the reliability of all constructs is satisfactory and exceeded the lowest cut-off value of 0.70 as recommended by Pallant (2010).

Additionally, confirmatory factor analysis was conducted to confirm the existence of convergent validity. This procedure was executed to ensure that each group of items that are supposed to measure a certain construct are in fact measuring it. The other purpose of confirmatory factor analysis is to support the assumptions of content validity and solves the issues of Multicollinearity. As the measurement items of constructs were adapted from previous studies, confirmatory factor analysis rather than exploratory factor analysis was executed. The procedure for conducting factor analysis was executed using AMOS 18 through the measurement model which included all items. The results showed that the factor loadings of all items ranged from 0.48 to 0.82 . Based on these results, it can be said that all items achieved the lowest recommended value based on the suggestions of Hair el al. (2010). Hence, the results of factor analysis are acceptable for all constructs.

After attaining acceptable values of factor loading on all items through the measurement model, the following step was to test the structural model. In this process, the most important thing is to ensure the goodness of model fit according to a number of fit values. Figure 1 indicated that the structural model achieved a good fit for the data, where the value of Chi-square is equal to 145.954. Other fit criterions ( $\mathrm{df}=87, \mathrm{GFI}=0.926$, AGFI $=0.897$, TLI $=0.950, \mathrm{CFI}=959$, and RMSEA $=0.053$ ) were also used to provide further support for the Chi-square and meet the assumptions of goodness of model fit. From these findings, it can be concluded that the model achieved acceptable fit for the data.

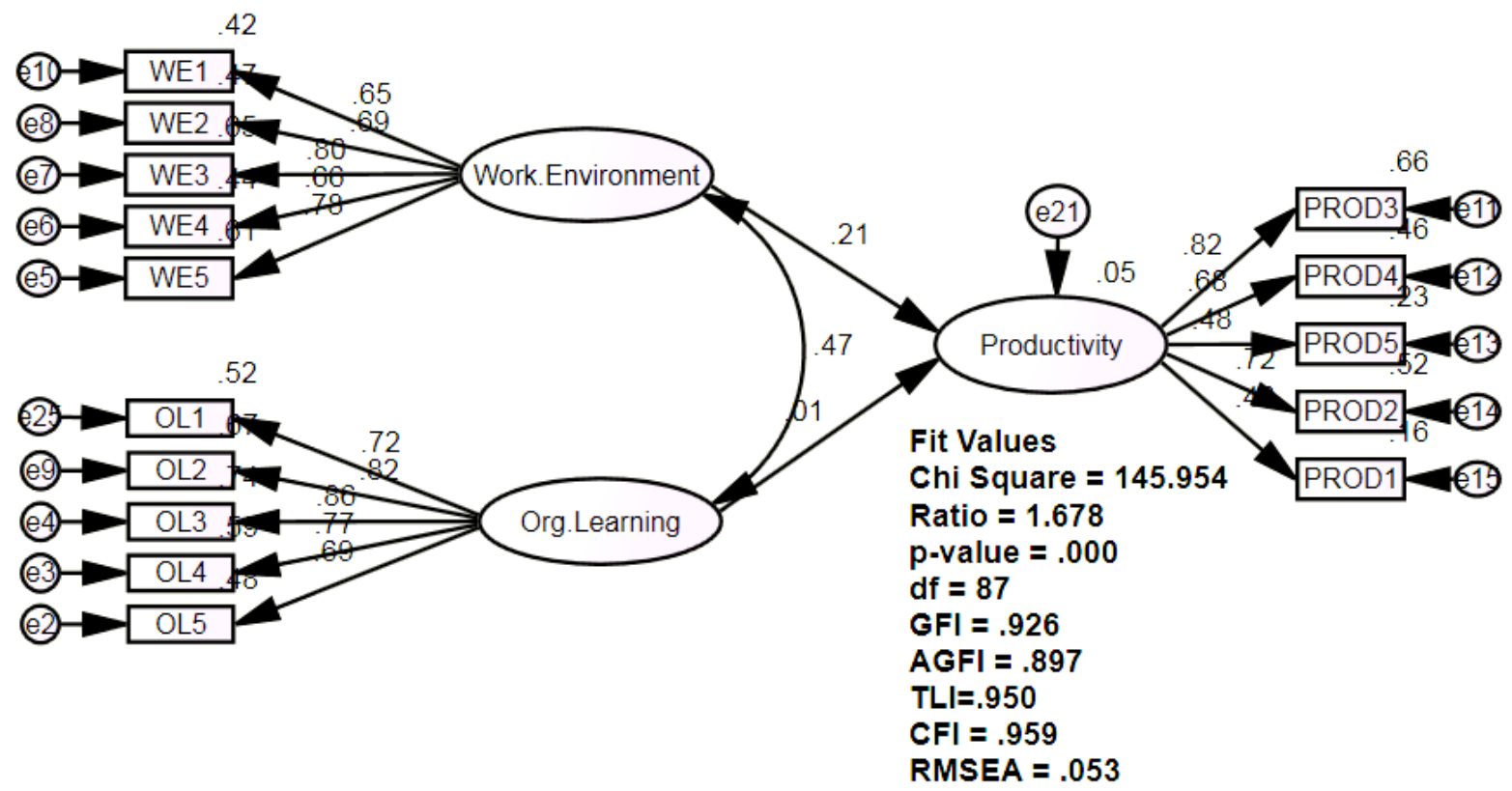

Figure 1. Structural Model 
To test the hypotheses which were presented earlier, the regression table was generated from the outputs of structural model. As shown in Table 2, the findings indicate that work environment has a significant positive effect on employee productivity $(\beta=0.213$, t-value $=$ 2.339, $\mathrm{p}<0.05)$, hence, $\mathrm{H} 1$ is accepted. Moreover, the effect of organizational learning on employee productivity is positive and statistically significant $(\beta=0.014$, $\mathrm{t}$-value $=4.125, \mathrm{p}<$ $0.05)$, consequently, $\mathrm{H} 2$ is supported. Overall, work environment and organizational learning has positive effects on employee productivity and play important roles in its improvement process.

Table 2. Results of Hypotheses

\begin{tabular}{llllllll}
\hline Hypothesized Effect & $\begin{array}{l}\text { Std. } \\
\text { Estimate }\end{array}$ & S.E. & C.R. & P & Support \\
\hline H1: & $\begin{array}{l}\text { Work environment has positive } \\
\text { effect on employee productivity. }\end{array}$ & 0.213 & 0.077 & 2.339 & 0.019 & Yes \\
H2: & $\begin{array}{l}\text { Organizational learning has positive } \\
\text { effect on employee productivity. }\end{array}$ & 0.014 & 0.029 & 4.125 & $* * *$ & Yes \\
\hline
\end{tabular}

\section{Discussion and Conclusion}

The rationale of this study was to test the effects of work environment and organizational learning on employee productivity in higher education sector. The findings indicated that work environment has a significant positive effect on employee productivity and it is in line with a number of previous studies (Foldspang et al., 2014; Awan \& Tahir, 2015; Ali et al., 2013). According to Ajala (2012), the environment of a workplace is the most critical factor for developing employee satisfaction and productivity. Sehgal (2012) added that, in order to increase employee productivity, the management should create a work environment where employees can enjoy their work, feel proud in what they do, and have the potential to reach their goals. This means that organizations can improve the productivity of their employees if they enhance the conditions of working environment and ensure employees' welfare. The practical implications from this result is that the management in higher educational institutions should put greater emphasis on creating a conducive workplace environment that can attract, sustain, and motivate the workforce for healthy living and increased productivity.

Moreover, the findings of this study revealed that organizational learning has significant positive effect on employee productivity. This result was supported by a number of previous studies which reported that organizational learning played an important role in driving the productivity of workers (Asadi et al., 2009; Davenport \& Prusak, 1998; Dusya, 2005). Christensen (2004) confirmed that organizations which move forwards through learning and flexible actions have better chances to increase their profitability. Moreover, Watkins and Marsick (1992) revealed that continuous learning programs form the basis for innovation which is fundamental for greater productivity. Herrera (2007) also illustrated that organizational learning plays an important role in improving employee's productivity. 


\section{Macrothink}

International Journal of Human Resource Studies

ISSN 2162-3058

2016, Vol. 6, No. 2

Therefore, organizational learning is an attempt on the part of an organisation to increase productivity, effectiveness and innovations in market conditions that are characterized by economic uncertainty economic and technological advancement. Given this result, it is suggested that organizations should focus on continuous organizational learning to upgrade the knowledge and skills of their employees for the purpose of ensuring organizational sustainability and productivity improvement.

This study has some limitations that should be considered in future researches. First, the respondents were only limited to the employees at public universities in northern area of Malaysia. Therefore, future research should test the variables under consideration in different industry context and cover others areas or regions. Additionally, a survey method was utilized for data collection, thus, qualitative methodologies may yield different outcomes. Moreover, in this study, only two constructs were examined to test their effects on employee productivity. Future researches should include other variables such as technology implementation and work specialization. Finally, the data of this study were collected through an online questionnaire. Face to face survey may increase the percentage of response to ensure higher representation of the population.

\section{References}

AbbasKhani, Y., Alipour, H., \& Ebrahimpour, H. (2013). Organizational learning and human resource productivity in municipality of Ardabil city. Singaporean Journal of Business, Economics and Management Studies, 2(3), 56-62.

Abdi, J., \& Khodadadi, G. (2014). Organizational learning, learning organization, and its effects upon productivity. Arthprabandh: A Journal of Economics and Management, 3(10), 157-169.

Adamu, S. O. (1991). Productivity data and nation building. Journal of Industrial Relation, 5, 21-26.

Ajala, E. M. (2012). The influence of workplace environment on workers' welfare, performance and productivity. The African Symposium: An Online Journal of the African Educational Research Network, 12(1), 41-149.

Akinyele, S. T. (2007). A critical assessment of environmental impact on workers productivity in Nigeria. Research Journal Business Management, 1(1), 50-61.

Ali, A. Y. S., Ali, A. A., \& Adan, A. A. (2013). Working conditions and employees' productivity in manufacturing companies in sub-Saharan African context: Case of Somalia. Educational Research International, 2(2), 67-78.

Allen, W., Kilvington, M., \& Horn, C. (2002). Using participatory and learning-based approaches for environmental management to help achieve constructive behaviour change. Landcare Research Contract Report: LC0102/057. Prepared for: Ministry for the Environment, Wellington, New Zealand.

Argote, L., \& Miron-Spektor, E. (2011). Organizational learning: From experience to 
knowledge. Organization science, 22(5), 1123-1137.

Asadi, H., Ghorbani, M. H., \& Naderan, M. (2009). The relationship between the learning organization and productivity in Iran physical education organization. World Journal of Sport Sciences, 2(3), 160-164.

Awan, A. G., \& Tahir, M. T. (2015). Impact of working environment on employee's productivity: A case study of Banks and Insurance Companies in Pakistan. European Journal of Business and Management, 7(1), 329-347.

Chen, Y., \& Tjosvold, D. (2008). Collectivist values for productive teamwork between Korean and Chinese employees. Working Paper Series, Centre for Asian Pacific Studies. Retrieved June 19, 2015, from http://commons.In.edu.hk/cgi/viewcontent.cgi?article=1002\&context=capswp

Dale, M. (1994). Learning organizations: Managing learning, Cengage Learning EMEA, 22-33.

Davenport, T. H., \& Prusak, L. (1998). Working knowledge: How organizations manage what they know. Harvard Business Press.

Dusya, V. (2005). Organization learning, knowledge management and intellectual capital: an Integrative Conceptual Model. Handbook of Organizational Design, 3-27.

Foldspang, L., Mark, M., Hjorth, L. R., Langholz-Carstensen, C., Poulsen, O. M., Johansson, U., \& Rants, L. L. (2014). Working environment and productivity: A register-based analysis of Nordic enterprises. Nordic Council of Ministers.

Greef, M. D., Broek, K., Jongkind, R., Kenny, L., Shechtman, O., \& Kuhn, K. (2004). Quality of the working environment and productivity: Research findings and case studies. European Agency for Safety and Health at Work.

Hair, J. F., Jr., Black, W. C., Babin, B. J., Anderson, R. E., \& Tatham, R. L. (2010). Multivariate data analysis (7th ed.). Upper Saddle River, N.J: Pearson Prentice Hall.

Herrera, D. A. (2007). A validation of the learning organization as a driver of performance improvement. ProQuest.

Huber, G. P. (1991). Organizational learning: The contributing processes and the literatures. Organization science, 2(1), 88-115.

Joo, B. K., \& Park, S. (2010). Career satisfaction, organizational commitment, and turnover intention: The effects of goal orientation, organizational learning culture and developmental feedback. Leadership \& Organization Development Journal, 31(6), 482-500.

Lambert, S. J. (2000). Added benefits: The link between work-life benefits and organizational citizenship behavior. Academy of Management Journal, 43(5), 801-815.

Lee, S. Y., \& Brand, J. L. (2010). Can personal control over the physical environment ease distractions in office workplaces? Ergonomics, 53(3), 324-335. 


\section{Al Macrothink}

International Journal of Human Resource Studies

ISSN 2162-3058 2016, Vol. 6, No. 2

Love, P. E., Li, H., Irani, Z., \& Faniran, O. (2000). Total quality management and the learning organization: a dialogue for change in construction. Construction Management \& Economics, 18(3), 321-331.

Mali, P. (1978). Improving total productivity. Wiley: New York.

Mawson, A. (2002). The workplace and its impact on productivity. Advanced Workplace Associates, London.

McGuire. D., \& McLaren, L. (2009). The impact of physical environment on employee commitment in call centres: The mediating role of employee well-being. Team Performance Management: An International Journal, 15(1/2), 35-48.

Nakpodia, E. D. (2011). Work environment and productivity among primary school teachers in Nigeria. African Research Review, 5(5), 367-381.

Opperman, C. S. (2002). Tropical business issues. Partner Price Water House Coopers.

Pallant, J. (2010). SPSS: Survival manual (4th ed.), Berkhire: Open University Press.

Rollinson, D. (2008). Organisational behaviour and analysis: An integrated approach. Pearson Education.

Saari, S. (2006). Productivity theory and measurement in business. In Espoo, Finland: European Productivity Conference.

Sehgal, S. (2012). Relationship between work environment and productivity. International Journal of Engineering Research and Applications, 2(4), 1992-1995.

Sikalieh, D., \& Mutia, P. M. (2014). Work environment and its influence on productivity levels among extension officers in the ministry of agriculture in Kenya. Retrieved September 24, 2015, from http://erepo.usiu.ac.ke/handle/123456789/341

Taiwo, A. S. (2010). The influence of work environment on workers productivity: A case of selected oil and gas industry in Lagos, Nigeria. African journal of business management, 4(3), 299-307.

Vasenska, I. (2013). Organizational learning and employee empowering increasing tourist destination performance. In Proceedings of the Management, Knowledge and Learning International Conference, 615-624.

Vischer, J. C. (2007). The effects of the physical environment on job performance: towards a theoretical model of workspace stress. Stress and Health, 23(3), 175-184.

Watkins, K. E., \& Marsick, V. J. (1992). Building the learning organisation: A new role for human resource developers. Studies in continuing education, 14(2), 115-129.

Winter, S. (2000). The satisficing principle in capability learning. Strategic Management Journal, 21(10/11), 981-996.

Yoldas, S. (2012). A Research about buying behaviours of online customers: Comparison of 
Turkey with UK (Master's Dissertation, University of Roehampton).

\section{Appendix}

Appendix 1. Measurement Scales of Constructs

\section{Code Construct/Item Factor \\ Loading}

\section{Work Environment (Cronbach's Alpha $=\mathbf{0 . 8 3 7})$}

WE1 I am satisfied with the space allocated for me to do my work. $\quad 0.65$

$\begin{array}{ll}\text { WE2 My workplace is very clean. } & 0.69\end{array}$

WE3 There is adequate space between me and my nearest colleague. $\quad 0.80$

WE4 My work environment is quiet. 0.66

WE5 Overall, my work environment is pleasant and visually 0.78 appealing.

\section{Organizational Learning $($ Cronbach's Alpha $=\mathbf{0 . 8 8 1})$}

OL1 Our institution creates continuous learning opportunities. $\quad 0.72$

OL2 Our institution encourages knowledge sharing among the staff 0.82

OL3 The leader of our institution supports learning at the individual, 0.86
team, and organization levels.

OL4 Our institution establishes systems to capture and share 0.77
learning.

OL5 Our institution connects the staff to the environment through 0.69
various programs.

Employee Productivity (Cronbach's Alpha = 0.755)

$\begin{array}{ll}\text { PROD1 I do large amount of work every day } & 0.49\end{array}$

$\begin{array}{lll}\text { PROD2 I accomplish tasks quickly and efficiently. } & 0.72\end{array}$ 
PROD3 I have a high standard of task accomplishment.

PROD4 My work outcomes are of high quality.

0.68

PROD5 I always beat our team targets.

0.48

\section{Copyright Disclaimer}

Copyright for this article is retained by the author(s), with first publication rights granted to the journal.

This is an open-access article distributed under the terms and conditions of the Creative Commons Attribution license (http://creativecommons.org/licenses/by/3.0/). 